The University of San Francisco

USF Scholarship: a digital repository @ Gleeson Library |

Geschke Center

School of Education Faculty Research

School of Education

2015

\title{
Nonformal Bilingual Education
}

Lesley Bartlett

Monisha Bajaj

University of San Francisco, mibajaj@usfca.edu

Follow this and additional works at: http://repository.usfca.edu/soe_fac

Part of the Bilingual, Multilingual, and Multicultural Education Commons

\section{Recommended Citation}

Bartlett, L. \& Bajaj, M. (2015). Nonformal bilingual education. In W. Wright, S. Boun \& O. Garcia (Eds.), The handbook of bilingual and multilingual education (pp. 428-446). Hoboken, NJ: Wiley-Blackwell. ISBN: 978-1-118-53349-9

This Book Chapter is brought to you for free and open access by the School of Education at USF Scholarship: a digital repository @ Gleeson Library | Geschke Center. It has been accepted for inclusion in School of Education Faculty Research by an authorized administrator of USF Scholarship: a digital repository@Gleeson Library| Geschke Center. For more information, please contact repository@usfca.edu. 


\title{
25 Nonformal Bilingual Education
}

\author{
LESLEY BARTLETT AND \\ MONISHA BAJAJ
}

\section{Introduction}

Globalization, or the increased flow of capital, goods, people, and ideologies across state borders, has profoundly influenced the rate of language change through at least two key processes. First, the world has witnessed the spread of world languages. Currently, 11 languages-Mandarin, Spanish, English, Hindi, Arabic, Portuguese, Bengali, Russian, Japanese, Punjabi, and German-are spoken by almost $50 \%$ of humanity. Second, with global flows of people, immigrant populations increasingly bring one or more languages with them to new locations, where they often must learn new languages.

In such circumstances, many seek out opportunities to learn a new language through formal schooling. However, an incalculable number, and particularly outof-school youth and adults, seek less formal means of learning an additional language. This chapter reviews an important but understudied phenomenon: nonformal bilingual education efforts. These efforts may be planned, that is, organized through nonformal educational programs or projects, or they may be informal and unplanned (García, 2009, 2013). As García $(2009$, 2013) has pointed out, nonformal out-of-school contexts include sites such as nongovernmental organizations and community-based organizations; they also include technology-enabled independent learning, families, religious groups, and playgroups. In some cases, community organizations utilize school auditoriums or facilities on weekends for bilingual education initiatives and these we have characterized as nonformal spaces since instructors and curricula are outside the purview of government mandate or control.

Insufficient attention has been paid to informal language learning outside of school. It is important to remember that much bilingualism develops without formal schooling. Krashen (1985) has distinguished between informal language acquisition, which entails "picking up" a language through interactions with family

The Handbook of Bilingual and Multilingual Education, First Edition. Edited by Wayne E. Wright, Sovicheth Boun, and Ofelia García.

(C) 2015 John Wiley \& Sons, Inc. Published 2015 by John Wiley \& Sons, Inc. 
members, community members, colleagues, and through the media, and language learning, through formal teaching in classrooms or intentional learning spaces. He emphasized that formal language learning needed to pay more attention to how people acquired language informally with more success, thus ushering in communicative approaches to language instruction. However, some use this distinction between acquisition and learning to suggest, erroneously, that acquisition is somehow unconscious (rather than unplanned). This chapter addresses that lacuna. As we describe below, informal bilingual acquisition may be unplanned or planned.

In this chapter, we discuss the distinction between planned and unplanned nonformal bilingual teaching and learning. Within each section, we focus on the domains that prompt bilingual language acquisition and use, including family, neighborhoods, media, religious organizations, and political groups. We review literature on nonformal bilingual education from around the world, considering in particular language efforts for and by immigrant populations. We focus on the rich theoretical developments in relation to a dynamic understanding of language socialization, identity and multilingual language and literacy practices. In the conclusion, we discuss future directions relevant to developing this topic, including the need for increased attention to translanguaging, questions regarding literacy learning in multiple languages, and more research on bilingualism and peace.

\section{Unplanned informal bilingualism}

Much bilingual acquisition occurs spontaneously, without planning from the state or programming by schools. For example, Batibo (2005) describes the language practices of a Tshivenda speaker in South Africa:

$[\mathrm{H}] \mathrm{e}$ may speak Tshivenda to his parents but use IsiZulu to address his workmates, and then receive orders from his employer in Afrikaans. But he may use English in a bank or when talking to educated strangers, and finally use Fanagalo in a pub with colleagues. To this Tshivenda speaker, each of these languages would provide not only a communicative function but also a social role. (cited in García, 2009, p. 47)

Indeed, informal bilingual acquisition characterizes the ways in which most people become bilingual. People acquire bilingualism informally through work, family, and community relations. Children may become bilingual through contact with caregivers, for example, when left in the care of Spanish- or Mandarinspeaking nannies in the United States, or from playing for long periods over many months with a friend who speaks another language.

Unplanned bilingual acquisition involves not only acquiring the language and using it in relationally and situationally specific settings, but also using it "in functional interrelationship for communicative and social benefit" (Martí et al., 2005, emphasis in original). Bilingual speakers pragmatically access and assess their multiple linguistic and cultural resources as they participate in plural social 
networks. As Pennycook (2000) argues, people do not use language based on their identities; instead, they perform their identities by using language. Such practices entail translanguaging, or dynamic engagement in multilingual reading, writing, listening, and speaking practices (García, 2009). For example, in bilingual homes, children may read mail or announcements in one language and orally translate to another language for family members. Bilingual children work as "language brokers" in public settings (Orellana, Reynolds, Dorner, \& Meza, 2003; Orellana, Thorne, Chee, \& Lam, 2001). When watching television with audio in one language that is subtitled in a second language, the watcher/listener is working across both languages; she or he may also be speaking to a person or explaining content in one of those or a third tongue.

Language socialization is a dynamic process and one that includes children and adults in community bilingual education efforts (García, 2009; Ochs \& Schieffelin, 1983; Schieffelin \& Ochs, 1986). Learners "exhibit considerable agency, choosing among options offered, and sometimes resisting and constructing new ways of using language and new identities" (García 2009, p. 207). Thus, the participatory and multiform nature of language socialization must be highlighted since learners may choose what to speak, when to engage accents of different sorts, and which aspects of their linguistic identity they seek to project in a given situation. Moreover, the linguistic practices and identities of a particular individual may change over his or her lifetime, influenced by location, sociopolitical events, labor market opportunities, kinship relations, among other factors (García, 2009; Luykx, 2003).

\section{Domains in unplanned nonformal bilingual acquisition}

The acquisition and learning of bilingualism in nonformal contexts varies across domains. Domains are areas of social life that may or may not be linked to specific social institutions; examples of domains include home, school, work, and religious institutions. Even as we consider how different domains afford different practices, we must remember that people move across domains and blend bilingual practices in their daily lives. For example, Gregory and Williams (2000) show how Gujarati Muslim children living in London bring with them to school capacities for memorization and reading experience working in larger groups and concentrating over an extended period of time, as a result of their engagement with Qur'anic texts.

In this section, we consider five domains that feature centrally in unplanned nonformal bilingual acquisition: home, neighborhood, immigrant communities, media, and work. We acknowledge, however, that the boundaries between domains are often blurred or situational, resulting in a variety of experiences that transcend such a divisions.

Home: Family members and caregivers Homes are, obviously, an important locus of unplanned bilingual acquisition. Children may learn a "mother tongue" at home that is quite distinct from the language or languages required in the marketplace or at school. Families organize their resources to benefit the intellectual 
and linguistic development of children (Arzubiaga, Ceja, \& Artiles, 2000; Arzubiaga, Rueda, \& Monzó, 2002; Arzubiaga, Noguerón, \& Sullivan 2009; Menard-Warwick, 2007; Sanchez \& Orellana, 2006). Parents may insist on bilingual acquisition in order to maintain family connections (Choudhury, 2013). Grandparents and grandchildren may provide a mutually supportive context for language learning (Gregory et al., 2004; Kenner et al., 2007). Children themselves play an important role as language brokers or cultural and language mediators (Dorner, Orellana, \& Li-Grining, 2007; Sanchez \& Orellana, 2006). Furthermore, siblings play a significant role in the language socialization of their younger brothers and sisters (de la Piedra \& Romo, 2003; Gregory, 2001). Research has shown that caregivers' language use and conversational styles influence children's bilingual development. Interrogatives, in particular, affect language development because they oblige the child to take his or her turn in conversation (Nakamura \& Quay, 2012). Gender also influences language acquisition since girls may be called upon more frequently to care for elders, may be more pressured to stay at home in some immigrant communities, and may have their marriage prospects more strongly linked to evidence of language and cultural maintenance in immigrant communities or ethnic enclaves with strong transnational linkages (Rumbaut, 1994).

Language acquisition at home may also relate to spatial and temporal conceptions of nationhood and belonging. Immigrants who see their stays in a host country as temporary may want their children to retain cultural, performing arts, religious, or other traditions that require language maintenance (García, Zakharia, \& Octu, 2013). With satellite television and technology that enables frequent and inexpensive video contact, even when return may not seem feasible, the maintenance of contact with family members in different countries may facilitate greater exposure to heritage languages and the desire for their acquisition and maintenance. Local and transnational communities are also bound together by events such as the international Urdu language poetry competition-where contestants submit videos of their recitation of original poems that are judged on technique, rhyme, wording, and flow. Past winners have been from New York, Saudi Arabia, Pakistan, and Texas (Mehfil-e-Mushaira, 2013). In New York City, a local but thoroughly pan-Latin American immigrant Spanish-language spelling bee is held each year with participants competing for recognition and prizes (Makar, 2013). The relationship between home and community influences how languages are prioritized, passed on, and acquired in distinct contexts.

Neighborhoods and peer groups Neighborhoods provide interesting and diverse language ecologies that spur the acquisition of bilingualism. For example, the bilingual practices of Latinos in the United States have been well documented. In Growing Up Bilingual, Zentella (1997) explores the language use of five Puerto Rican New York girls who were raised in bilingual homes in the same building in El Barrio, or Spanish Harlem. The young women were exposed to varieties of Spanish such as popular and standard Puerto Rican Spanish, as well as popular and standard forms of English. The girls also participated in social 
networks where other varieties of Spanish and English were spoken, including African American Vernacular English and Dominican Spanish.

Such linguistic diversity characterizes many areas of Africa. It is unfortunate that most language education policy ignores these linguistic capacities. Drawing on the experience of a school in the Western Cape Province of South Africa, and using a "speaker-centered approach to school language policy," Busch (2010, p. 283) demonstrates that students' diverse multilingual repertoires "are, within the education system, reduced to an either-or monolingualism-in the case discussed above, either to English or to Afrikaans." Busch describes this process, in which the language capacities and practices of students in their daily lives are ignored in school, as "monolingualization."

Borders are particularly interesting locations of bilingualing practices. A great deal of attention has been focused on the U.S.-Mexico border, leading scholars to examine closely what they are calling transfronterizo language and literacy practices (see the 2012 special issue of International Journal of Bilingual Education and Bilingualism, 15(6)). In many locations, certain languages are prohibited, shifting language practices. For example, in many government secondary schools in Zambia where English is the language of instruction, children are beaten or punished for using home languages (whether languages from the Congo spoken by refugees on the border, or one of Zambia's 70 indigenous languages and dialects) (Bajaj, 2009). Waltermire (2012) demonstrates how the Uruguayan prohibition of Portuguese in schools along the Uruguayan-Brazilian border caused the language to become more restricted to the home, where it is used with relatives and close friends.

However, there is ample evidence of the spread of transnational languaging and literacies. Transnational literacies describe "the written language practices of people who are involved in activities that span national boundaries" (Jimenez, Smith, \& Teague, 2009, p. 17), including letters, emails, texts, remittances (economic and social), etc. These correspondences and encounters facilitate people's maintenance of language, culture, and social bonds with family members in their home countries (Smith \& Murillo, 2012; de la Piedra \& Guerra, 2012). These practices can foster fluency in learners' mother tongue and reshape identities and notions of belonging along local and global dimensions (Guerra, 1998; Farr, 1994).

Immigrant communities. Immigrant communities form a particularly important language resource in many parts of the world. For example, Kalmar (2000, p. 59) documents the delightfully imaginative approach developed by a group of undocumented immigrants living in a rural part of southern Illinois, who helped each other write down English "como de veras se oye" (as it really sounds). They developed a unique, hybrid writing system "by letting letters of an alphabet take on values on a sliding scale between speech sounds in a known language and those in the unknown language." In brief, the workers used their knowledge of the Spanish alphabet to record speech sounds of English.

In communicating with shopkeepers, religious figures, or others in immigrant communities, learners often have to practice languages that they may hear at 
home, but do not learn formally at school. Such interactions in communitiesoften related to festivals, performances, political organizing, or other events-are not intended necessarily to promote language learning but do so as a byproduct of social interactions. For example, a New York Times article highlighted Punjabi broadcasters in Toronto who narrate Canadian hockey games in the Punjabi language given the immigrant community's interest in the sport (Sax, 2013).

Media This process of community bilingual acquisition has been assisted and supported by different forms of media and technology. As García (2009) describes, voice over Internet Protocol (VOIP), which converts voice signals into digital signals that can travel over the internet, has allowed people to maintain voice contact for no or low fees, thus expanding cross-national and multi-lingual conversations. Mobile phones, with their capacity for Short Text Messages (SMS or Short Message Service), also facilitate such communication; they have also been explored as media through which to distribute texts and oral readings in various languages. In their study of everyday mobile phone use by Indigenous people in a remote Australian community, Auld, Snyder, and Henderson (2012) demonstrate the possibilities of using mobile phones to promote multilingualism and literacies. Subtitles on television shows spread opportunities for learning multiple languages and literacies: Pederson (2011) describes how Swedish subtitles for Englishmedium television shows promote bilingualism. The greater availability of DVDs has afforded viewers the options of hearing movies dubbed into different languages or reading subtitles. For example, scholars have reported women in Tehran learning English through series such as Lost and Friends (Amina Tawasil, personal communication, 2013). Achen and Openjuru (2012) described the watching and reviewing of English-language Hollywood movies in makeshift video hall shacks in Kampala, with simultaneous oral interpretation of the films into Luganda. They discussed how "new forms of cultural representation are created, consumed and shared through digital and other media," as well as "the effects digital technology has on the local movie entertainment industry" (Achen \& Openjuru, 2012, p. 363). The global spread of Bollywood movies has facilitated diasporic South Asian communities' use of language, movie dialogues, and fashion to shape their identities in diverse locales such as the Middle East, sub-Saharan Africa, Canada, the United States, and Europe (Shankar, 2004). Finally, recent work has documented the intergenerational language learning that may occur around computers, such as when grandparents in Sylheti/Bengali-speaking families in East London combined their knowledge of literacy with the grandchildren's computer skills and cultural knowledge (Kenner et al., 2008).

Work Workplaces are important but often-overlooked contexts of nonformal bilingual acquisition. Velasquez (2013) explores the obstacles faced by undocumented Latino immigrants primarily from Mexico, Ecuador, and Guatemala who work in restaurants and supermarkets in Koreatown in New York City. Underground employment agencies often find work for undocumented Latino immigrants in ethnic supermarkets in Koreatown. The informal contact facilitates 
language sharing between workers who speak Korean, English, Spanish, and sometimes indigenous languages of Latin America like Kaqchiquel. In workplaces where Latino and Korean employees work together, speakers combine and mix languages, resulting in what Velasquez (2013) calls "work pidgins." Notably, much of the knowledge undocumented Latinos need and consider important comes from other immigrants in out-of-school contexts like the workplace. Other work has documented multilingual workplace languaging: for example, Kleifgen (2001) discusses social positioning between two Vietnamese workers in a circuit-board manufacturing plant, as they engage the system of person reference and English solidarity expressions to "troubleshoot" a malfunctioning machine and contest each other's solutions, and problem-solve.

The review of examples of unplanned bilingual acquisition from across the globe demonstrates four principles that have been identified by Ofelia García (2009). First, unplanned bilingual education is common in the industrialized and developing world. Second, it is contingent on participation in diverse social networks and formations and, thus is often far more complex than planned efforts. Third, hybrid language practices emerge in unplanned bilingual education such as translanguaging, and demonstrate a "heteroglossic language ideology" (García, 2009 , 211). Fourth, as García (2009, p. 211) highlights, unplanned bilingual education is based on "functional interrelationships that maintain an adjusting language ecology."

\section{Planned nonformal bilingualism}

Planned informal bilingual efforts often result from communities who sense a need to maintain a language that is perceived to be under threat, and from the realization that, even if taught at school, minoritized languages need to be reinforced beyond formal schooling (Fishman, 1991). Like unplanned bilingual acquisition, much planned bilingual learning occurs through families and the media. In addition, it is important to consider the efforts of community groups, refugee camp and refugee/migrant learning centers, religious organizations, cultural/ recreational groups, and political/national groups. Such efforts represent an intentional effort to recruit or engage speakers of a particular language and are unique to the planned nonformal efforts.

\section{Domains in planned nonformal bilingual acquisition}

Home: Family members and caregivers Many families take a more intentional and deliberate approach to what Ofelia García has called "family bilingual planning," given the growing consciousness of the potential of language learning as well as the need or desire among many to maintain transnational and multigenerational ties. For example, in Wales, parents who visit family planning clinics are now also given information about language planning for their children (Edwards \& Newcombe, 
2006). Similarly in Scotland, official support through materials such as The Family Language Action Plan, is offered to families to promote their use of the Gaelic language with their children (García, 2009).

Those families with sufficient means also make planned decisions related to short-term migration based on linguistic goals. For example, an increasing number of Korean families move to English-speaking countries for short periods in order expose their children to English, a global language with currency for children. In a case study of ten Korean families who move to England, Moon (2011) finds that families are in part motivated by a desire for children to acquire English early as well as dissatisfaction with the Korean education system. Onishi (2008) has documented families that split up, with fathers remaining in Korea and mothers and children pursuing education abroad in Western countries, partially motivated by a desire for language acquisition. Many Asian countries are in the grips of what Park (2009) and others have termed "English fever" with a desire for fluency, accent reduction, and overall competitive advantage for children who will compete in a global marketplace.

Media Planned bilingualism in nonformal contexts is greatly facilitated by new technologies and products. Many products offer interactive lessons and audio downloads or discs that can be listened to while doing daily tasks. Downloads, apps, podcasts, websites, and other free and fee-based technologies offer new opportunities for individuals and families to utilize the media to plan language acquisition. Learners also have greater opportunities to seek out forms of media that support their learning and maintenance of a language (Lam \& Rosario-Ramos, 2009). Access to satellite radio, internet stations, or newspapers from different countries in different languages has reached unprecedented levels.

While individuals seeking to learn global languages have increasing access, many languages that have not been extensively written down or for which materials are scarce, provide learners with greater difficulties. Despite the fact that the 1996 South African Constitution offers a significant commitment to multilingualism, the paucity of teaching and learning materials in South African languages has limited the reach of bilingual education. Edwards and Ngwaru (2011) have explored challenges to the production of children's literature in local languages, including the economics of producing books, obstacles related to translation, and the challenges of working with diverse languages that have undergone varying degrees of standardization. Scholars have documented the challenges faced by projects such as the Ithuba Writing Project in South Africa that attempt to develop culturally relevant, linguistically appropriate, leveled teaching and learning materials in under-represented languages (Sailors, Hoffman, \& Condon, 2009).

Community groups Across the globe, community-based programs, such as camps, weekly language centers, clubs, and performing groups, have sought to infuse planned nonformal bilingual education. For indigenous peoples, language revitalization initiatives often seek to link to community practices, especially in many 
contexts where languages are endangered. Sometimes, these efforts are exclusively focused on people with heritage from these linguistic groups; other times, dominant language communities are also included in language revitalization. García (2009, p. 199) has noted in her work on nonformal bilingual education the following:

This is also the source of the success of the so called "language nest" movements in places like Aotearoa/New Zealand and Hawaii. For example, Te Kōhanga Reo programs in New Zealand involve pre-school children under the age of five in centers where the whanau, or extended family, impart Māori spiritual values, language and culture. The concept of whanau also includes clusters of values: virtues of aroha (caring, sharing, and empathy), whanaungatanga (family responsibilities), rangimarie (peacefulness), and manaaki (kindness)... . It is the use of language informally, in authentic and meaningful culturally relevant ways that has succeeded in revitalizing the Māori language.

Whether through summer camps, playgroups, musical instruction, or clubs, bilingual community education is dynamic and active across the globe (García, Zakharia, \& Octu,, 2013). Scholars have researched four complementary schools for Bengali, Chinese, Gujarati, and Turkish speakers in Birmingham, Manchester, Leicester, and London, investigating interactions between language practices and multilingual, multicultural identities (Creese, Bhatt, Bhojani, \& Martin, 2006; Creese et al., 2008). Such efforts are not simple, however. For example, an ethnographic study conducted by Doerr and Lee (2009) at a weekend Japanese-language school in the United States showed that administrators, students, and parents may hold very different notions of "legitimate" and "effective" heritage-language programs. The authors "suggest approaching heritage-language education not merely as an effort to enhance awareness of one's heritage or an instruction in language but also as a schooling process in which legitimacy of the knowledge and ways to achieve it are contested in the process of students and parents navigating what school offers, the students' linguistic proficiencies, their future educational prospects, and their diasporic subjectivities" (Doerr \& Lee, 2009, p. 425). Such efforts link identity with language, particularly in the context of migration and pressures to assimilate into dominant and mainstream society.

Refugee/migrant learning centers and refugee camps In many areas of the world where immigrants gather in sufficient concentration, they form educational efforts. For example, on the border between Thailand and Burma/Myanmar, between 85 and 200 migrant learning centers (MLCs) have emerged to serve the needs of Burmese undocumented migrants. As documented by Kim Johnson (2013), MLCs serve students from various ethnic backgrounds, most of whom speak a mother tongue and Burmese as a second or third language; a few of these centers use Karen or another mother tongue as medium of instruction. Teachers within the centers are usually themselves undocumented migrants. Migrant learning centers are plagued by a lack of physical security and resources and high teacher and student turnover (Proctor, Sanee, \& Taffesse, 2009). 
Often, such language efforts participate in broader political projects. Kelda Jamison (2013) researches Kurdish instruction in Diyarbakir, the "capital" of Kurdish Turkey. Since the lifting of a state ban on Kurdish language use in 1991, Kurdish activists have worked to create dictionaries, grammar books, and a legitimate, respected orthography, as well as gender-segregated adult literacy classes for forcibly displaced Kurdish villagers. Jamison (2013, p. 1) highlights the political economy of language, including "the politics around which language is used for instruction, in what contexts, to what purposes, and with what histories of association."

In addition, such language politics are intimately connected to identity politics. Inmaculada García Sánchez (2010, 2011) investigates how North African immigrant children and youth in Spain develop a hybrid, yet coherent, sense of identity. She also examines language socialization among Muslim and non-Muslim peers as well as the sociocultural and linguistic lifeworlds of Moroccan immigrant children as they navigate family, educational institutions, and medical clinics where they act as translators. Overall, her work considers how immigrant children negotiate the immediate and broader, national politics of inclusion/exclusion in the context of increased levels of surveillance directed toward Muslim and North African immigrants.

Within refugee camps and other locations where large numbers of refugees are located, educational efforts may focus on learning the home language to prepare for repatriation, learning a world language in anticipation of repatriation or resettlement, or both. Thus, Ginger Johnson (2013) discusses how Sudanese women in Cairo seek English instruction for themselves and their children, in order to prepare their families for resettlement to an English-speaking country or to secure a livelihood for themselves if they return to economic centers in South Sudan. Similarly, in the context of significantly limited access to basic education in Kampala, Uganda, refugees of different nationalities have started self-help schools. Congolese refugee teachers set up the Kampala Urban Refugee Children's Education Centre (KURCEC), a refugee-initiated community-based organization, where instruction in French afforded the possibility that students can eventually repatriate to the DRC (Dryden-Peterson, 2006). Alternately, such language education efforts may focus on preparing students to integrate in the host country. For example, Lucy Karanja (2010) described a self-help Sudanese school in Nairobi, where although the media of instruction were English and Swahili, teachers and peers could explain concepts in Dinka, Nuer, and Arabic, as needed by students.

Religious organizations Many religious organizations plan and implement nonformal language instruction, especially where language is an integral part of understanding religious texts. For example, in their book on community bilingual education in New York City, García and colleagues (2013) highlight many examples of language instruction through organizations as diverse as the Greek Orthodox Church, Sikh temples or gurdwaras offering instruction in Punjabi, mosques teaching Arabic, synagogues offering instruction in Hebrew, among others. Even when language is not central to the understanding of religious texts, 
churches often provide a community center in which immigrant populations gather and can engage in language learning. For example, Lucila Ek (2005) describes the language socialization of immigrant Central American and Mexican youth in a Spanish-language Pentecostal church in southern California, an important domain of language socialization for immigrant communities. Similarly, in her ethnographic work with families from the African Great Lakes Region living in northeast Boston, Lamphere Beryl (2013) documents how families use Biblical stories to socialize children and the importance of language and literacy socialization that occurs in the Pentecostal churches the families attend.

In different global contexts, language learning can be a subversive act that threatens a government in power, and religious spaces may be one of few locales where those seeking to maintain a language can turn to. In Burma/Myanmar, for instance, the teaching of the Karen language or any other ethnic language has for decades been officially banned in public schools. To maintain their language, Karen communities have tried to teach Karen through religious activities, such as in Christian Sunday schools or Buddhist monasteries.

Other studies have examined how language maintenance occurs in settings where a language may not be banned, but shunned in the larger public domain perhaps leading to greater linguistic assimilation. In their study of Turkish and Moroccan communities in the Netherlands, Extra and Yagmur (2010) show dissonance between cultural identity and language use, with those Moroccan youth stating greater pride in their cultural background also being those less likely to speak their native language. For the Turkish youth in their study, however, pride in identity and Turkish language were more strongly linked according to the researchers suggesting differential ways that language and identity align among minoritized groups.

Literacy practices can also be generated in religious contexts and transferred more broadly for learners. De la Piedra (2010) finds that schools did little to promote the maintenance of Quechua language in Peru, whereas, for some participants in her study, authoring Quechua religious songs through participation in a Protestant church proved to be a more formative literacy maintenance practice. Thus, religious settings offer a space to engender bilingual practices that can translate into greater linguistic proficiency in distinct contexts.

Cultural/recreational groups Cultural traditions, sometimes linked to religious practices but often distinct, also provide ways for learners to engage in bilingualism in planned nonformal contexts. A volume documenting community bilingual education in New York City discussed several communities that had active and vibrant performing arts traditions that included language learning. A Bengali language school on the weekends in Queens emphasizes dance, drumming, and performance arts from Bangladesh; a Persian/Farsi children's theater offers youth a chance to engage with their cultural and linguistic heritage; and a weekend Russian program exposes young people to Russian literature, chess, and theater (García, Zakharia, \& Octu, 2013). Other ways that language learning in this domain occurs is through sports or other recreational activities that have a planned 
component, such as the Socrates LINGUA projects and other European programs that promote language learning through sports (Education, Audiovisual \& Culture Executive Agency, 2008).

Political/national groups Within community-based planned bilingual education efforts, a sense of nationhood is often palpable. For example, in the Bengali weekend program mentioned above, children recite both the U.S. and Bangladeshi national anthems at the start of their programs, whereas in a Turkish language program in New York City run through the Consulate, just the Turkish pledge of allegiance is recited (García, Zakharia, \& Octu, 2013). Many French-language programs and Spanish-language programs in the United States have support or contact with government officials from those countries.

Language diplomacy is an active and increasing component of international aid. The British Council is working with teacher education institutions in India to improve the teaching of English and the Confucius Institute is active in more than 90 countries and regions offering Chinese language instruction, primarily in schools. While not a nonformal effort, the Confucius Institute places Chinese language teachers in schools throughout the world, demonstrating a significant commitment to language diplomacy.

Other diplomacy efforts related to language take place outside of schools and through community-based organizations. The Brazilian government sustains Brazilian cultural centers in many countries throughout the world, where people may study Portuguese. The Qatar Foundation International (QFI) has supported an Arabic Language and Culture Program in São Paulo and Curitiba, Brazil for high school level students in and outside of schools. The outside-of-school component of the program offers cultural classes, exhibitions, story telling, dance and music. The participants in these programs do not have Arab heritage and the purpose of QFI's efforts is to give an opportunity to "lower-income students to learn Arabic and the Arab culture," according to one description of the program (https:/ / www.youtube.com/watch?v=ozyohquABzI). Cuba has long been active in "development diplomacy" by sending teachers and doctors to foreign countries as well as accepting low-income students to study medicine in Havana for free. While language is a small component of Cuba's efforts, students from Africa, South Asia, Latin America, and some poor students from the United States, must take an intensive 12-week course in Spanish before starting their medical studies. The medical school training lasts six years and full scholarships include meals, housing, books, and a small stipend. Students must return to work in their home countries in underserved communities upon completion.

While many language programs are sponsored by governments, others are political projects that seek to resist government conceptions of citizenship in conflict-affected areas. Nonformal bilingual education efforts can offer a radical reconceptualization of what it means to be a citizen and can help to develop solidarity with marginalized groups. For example, a nongovernmental organization in the Dominican Republic (Centro Bono) offers Haitian Creole classes that are attended by people of Haitian descent, social workers engaging with immigrant 
communities, and activists seeking to learn the language in solidarity with Haitian immigrants and people of Haitian descent who have historically been mistreated in the Dominican Republic. In Israel, while there are a handful of integrated, bilingual schools that have been discussed in scholarly literature (see, for example, Bekerman, 2005), there also exist nonformal efforts to bring Hebrew- and Arabicspeaking communities together with language learning as one component. Obviously, Haitian immigrants and Arab Israelis have a material interest in learning the language of those in power since few jobs would be available without such skills, but for dominant groups, the symbolic gesture of acquisition of the language of a marginalized group offers unique dimensions to the study of peace, the role of solidarity and language learning.

\section{Conclusions and future directions for research}

This review of existing literature documents the extent of nonformal, bilingual education that exists around the world and the various domains through which it operates. Most people develop some of their language resources through unplanned, nonformal means, even if they supplement such learning through formal schooling. However, unplanned nonformal bilingual acquisition has not received sufficient attention. Planned nonformal bilingual education has received only slightly more attention. In accordance with García $(2009,2013)$, we concur that "supplementary education" for bilingualism should give primacy to the speakers of a language rather than treating language as an object to be consumed or purchased; that language can complement but should not threaten other languages or identities; and that processes should be developmental as opposed to linear and be contextual. Supplementary planned language education, as García (2009) terms it, should not rely on traditional notions of language acquisition that separate two languages; rather translanguaging that is prevalent in practice should be engaged in these efforts.

There are important directions for further developing our knowledge of this topic. In this conclusion, we wish to briefly indicate two promising avenues: the need for increased attention to translanguaging, and the need for more research on bilingualism and peace.

\section{Translanguaging}

Ethnographic research on bilingual language practices makes clear how bilingual people draw simultaneously from and across their language resources, in some instances through micro-alternation between languages. Increasingly, scholars are questioning why language pedagogies do not recognize and build upon such practices (Cummins 2005; Lin \& Martin 2005; García 2009). Arthur and Martin (2006) discuss the pedagogical benefits of mixing languages, which include expanding inclusion, participation, comprehension, and ultimately learning 
among student participants. To develop pedagogical strategies that build on bilingual languaging resources, Cummins (2005, p. 588) suggested:

(a) systematic attention to cognate relationships across languages; (b) creation of student-authored dual language books by means of translation from the initial language of writing to the L2 [as well as] other multimedia and multilingual projects ... (e.g., creation of iMovies, PowerPoint presentations, etc.); (c) sister class projects where students from different language backgrounds collaborate using two or more languages.

Creese and Blackledge (2010, p. 112-113) suggest the following strategies for "flexible bilingualism":

1. Use of bilingual label quests, repetition, and translation across languages;

2. Ability to engage audiences through translanguaging and heteroglossia;

3. Use of student translanguaging to establish identity positions both oppositional and encompassing of institutional values;

4. Recognition that languages do not fit into clear bounded entities and that all languages are "needed" for meanings to be conveyed and negotiated;

5. Endorsement of simultaneous literacies and languages to keep the pedagogic task moving;

6. Recognition that teachers and students skillfully use their languages for different functional goals such as narration and explanation;

7. Use of translanguaging for annotating texts, providing greater access to the curriculum, and lesson accomplishment.

Such efforts also open important questions about the cognitive, linguistic, and political limits of transfer of such pedagogies that merit further research (Arthur \& Martin, 2006; Creese \& Blackledge, 2010; see also Chapter 13 Translanguaging, Bilingualism, and Bilingual Education).

\section{Bilingual education and peace}

A second area in need of research concerns the relationship between bilingual education and peace. The impact of bilingual education on attitudes toward peace and conflict in general has not been fully examined; and bilingual and integrated education experiences in conflict areas have been even less addressed. In addition, there is a lack of knowledge on the motivation, challenges, and views of parents who enroll their children in these types of schools. Further, there are few studies on how bilingual education affects relations between dominant and less dominant, minority (or minoritized) and majority groups, in conflict areas, and there is an even greater dearth of research on bilingual education as a tool for promoting peace and understanding between two conflicted groups (Bekerman \& Shhadi, 2003). The limited studies on the topic assert that bilingualism can bring about 
greater understanding among groups and an increased knowledge of each other. In fact, García and Fishman (1997, p. 406) claim that "bilingualism creates a greater understanding that is beyond multicultural education and the anti-racist education movement." Such a conclusion is based on the assumption that a deeper understanding of the language of the "other group" increases the person's ability to empathize with, comprehend, and even explain actions and attitudes expressed by the other.

Bilingual education can also serve as an effective empowerment tool for less dominant groups when their needs and desires are taken into consideration. Minority members are often deprived of equal or fair access to resources. Thus, whenever the contact with the majority is carefully constructed to produce a positive change in participants' attitudes and behaviors, the minority members report a sense of empowerment resulting from the contact (see, e.g., Abu-Nimer, 2001). Different models of bilingual education strive to achieve this goal, while others do not challenge the asymmetric power relations that exist between the conflicted groups in schools and in the larger society. The best results are attained when the minority language is given greater weight to balance the dominance of the majority language. Models that offer minority languages only in lessons once or twice a week in the curriculum sustain the unequal status quo between the two languages and peoples (García \& Fishman, 1997).

In conclusion, greater research on planned and unplanned community and nonformal bilingual education is needed with attention to translanguaging pedagogies and the possibilities of engaging in bilingual education to promote peace. Attending to the agency of speakers and learners and the processes and contexts in which they engage bilingualism will yield greater information to highlight the dynamism of language learning in the global era.

\section{REFERENCES}

Abu-Nimer, M. (2001). Conflict resolution, culture, and religion: Toward a training model of interreligious peacebuilding. Journal of Peace Research, 38, 685-704.

Achen, S., \& Openjuru, G. (2012).

Hollywood in Uganda: Local appropriation of trans-national Englishlanguage movies. Language and Education, 26(4), 363-376.

Arthur, J., \& Martin, P. (2006).

Accomplishing lessons in postcolonial classrooms: Comparative perspectives from Botswana and Brunei Darussalam. Comparative Education, 42, 177-202.
Arzubiaga, A., Ceja, M., \& Artiles, A. J. (2000). Transcending deficit thinking about Latinos' parenting styles: Toward an ecocultural view of family life. In C. Tejeda, C. Martinez, \& Z. Leonardo (Eds.), Charting new terrains of Chicana(o)/ Latina(o) education (pp. 93-106). Cresskill, NJ: Hampton Press.

Arzubiaga, A., Noguerón, S. C., \& Sullivan, A. L. (2009). The education of children in immigrant families. Review of Research in Education, 33, 246-71.

Arzubiaga, A., Rueda, R., \& Monzó, L. (2002). Family matters related to the 
reading engagement of Latino children. Journal of Latinos and Education, 1, 231-243.

Auld, G., Snyder, I., \& Henderson, M. (2012). Using mobile phones as placed resources for literacy learning in a remote Indigenous community in Australia. Language and Education, 26(4), 279-296.

Bajaj, M. (2009). "I have big things planned for my future": The limits and possibilities of transformative agency in Zambian schools. Compare: A Journal of Comparative and International Education, 39(4), 551-568.

Batibo, H. M. (2005). Language decline and death in Africa: Causes, consequences and challenges. Clevedon, UK: Multilingual Matters.

Bekerman, Z. (2005). Complex contexts and ideologies: Bilingual education in conflict-ridden areas. Journal of Language Identity and Education, 4(1), 21-44.

Bekerman, Z., \& Shhadi, N. (2003). Palestinian Jewish bilingual education in Israel: Its influence on school students. Journal of Multilingual and Multicultural Development, 24(6), 473- 484.

Busch, B. (2010). School language profiles: Valorizing linguistic resources in heteroglossic situations in South Africa. Language and Education, 24(4), 283-294.

Choudhury, R. (2013). Raising bilingual and bicultural Bangladeshi-American children in New York City. In O. García, Z. Zakharia, \& B. Otcu (Eds.), Bilingual community education for American children: Beyond heritage languages in a global city (pp. 60-73). Bristol, UK: Multilingual Matters.

Creese, A., Barac, T., Bhatt, A., Blackledge, A., Hamid, S., \& Wei, L. (2008). Investigating multilingualism in complementary schools in four communities (Final Report to ESRC RES-000-23-1180). Birmingham: University of Birmingham.

Creese, A., \& Blackledge, A. (2010). Translanguaging in the bilingual classroom: A pedagogy for learning and teaching? Modern Language Journal, 94, 103-115.

Creese, A., Bhatt, A., Bhojani, N., \& Martin, P. (2006). Multicultural, heritage and learner identities in complementary schools. Language and Education, 20, 23-43.

Cummins, J. (2005). A proposal for action: Strategies for recognizing heritage language competence as a learning resource within the mainstream classroom. Modern Language Journal, 89, 585-592.

de la Piedra, M. T. (2010). Religious and self-generated Quechua literacy practices in the Peruvian Andes. International Journal of Bilingual Education and Bilingualism, 13(1), 99-113.

de la Piedra, M. T., \& Guerra, J. (2012). The literacy practices of transfronterizos in a multilingual world. International Journal of Bilingual Education and Bilingualism, 15(6), 627-634.

de la Piedra, M. T., \& Romo, H. D. (2003). Collaborative literacy in a Mexican immigrant household: The role of sibling mediators in the socialization of preschool learners. In R. Bayley, \& S. R. Schecter (Eds.), Language socialization in bilingual and multilingual societies (pp. 44-61). Clevedon, UK: Multilingual Matters.

Doerr, N. M., \& Lee, K. (2009). Contesting heritage: Language, legitimacy, and schooling at a weekend Japanese-language school in the United States. Language and Education, 23(5), 425-441.

Dorner, L. M., Orellana, M. F., \& Li-Grining, C. (2007). "I helped my mom," and it helped me: Translating the skills of language brokers in improved standardized test scores. American Journal of Education, 113, 451-478.

Dryden-Peterson, S. (2006). "I find myself as someone who is in the forest": Urban refugees as agents of social change in Kampala, Uganda. Journal of Refugee Studies, 19(3), 381-395. 
Education, Audiovisual \& Culture

Executive Agency. (2008). Languages meet sport: Promoting languages through sport. Brussels: European Commission.

Edwards, V., \& Newcombe, L. P. (2006). Back to basics: Marketing the benefits bilingualism to parents. In O. García, T. Skutnabb-Kangas, \& M. Torres-Guzman (Eds.), Imagining multilingual schools: Languages in education and globalization (pp. 137-149). Clevedon, UK:

Multilingual Matters.

Edwards, V., \& Ngwaru, J. M. (2011). African language publishing for children in South Africa: Challenges for translators. International Journal of Bilingual Education and Bilingualism, 14(5), 589-602.

Ek, L. D. (2005). Staying on God's path: Socializing Latino immigrant youth to a Christian Pentecostal identity in Southern California. In A. C. Zentella (Ed.), Building on strength: Language and literacy in Latino Families and Communities (pp. 77-92). New York: Teachers College Press.

Extra, G., \& Yagmur, K. (2010). Language proficiency and socio-cultural orientation of Turkish and Moroccan youngsters in the Netherlands. Language and Education 24(2), 117-132.

Farr, M. (1994). En los dos idiomas: Literacy practices among Mexicano families in Chicago. In B. Moss (Ed.) Literacy across communities (pp. 9-47). Cresskill, NJ: Hampton Press.

Fishman, J. A. (1991). Reversing language shift: Theoretical and empirical of assistance to threatened languages. Clevedon, UK: Multilingual Matters.

García, O. (2009). "Bilingualing" without schooling. The role of comprehensive education. In H. Varenne \& E. Gordon (Eds.), Theoretical perspectives on comprehensive education: The way forward (pp. 187-216). Lewiston, NY: Edwin Mellen Press.

García, O. (2013). Informal bilingual acquisition. Dynamic spaces for language education. D. Singleton, J. A. Fishman, L. Aronin, \& M. Ó. Laoire (Eds.), Current multilingualism: A new linguistic dispensation (pp. 99-118). Berlin, Germany: Mouton de Gruyter.

García, O., \& Fishman, J. (Eds.). (1997). The multilingual apple. Languages in New York City. Berlin, Germany: Mouton de Gruyter.

García, O., Zakharia, Z., \& Octu, B. (Eds.) (2013). Bilingual community education and multilingualism: Beyond heritage languages in a global city. Bristol, UK: Multilingual Matters.

García Sánchez, I. M. (2010). The politics of Arabic language education: Moroccan immigrant children's socialization into ethnic and religious identities. Linguistics and Education 21(3), 171-196.

García Sánchez, I. M. (2011). Language socialization and exclusion. In A. Duranti, E. Ochs, \& B. Schieffelin, (Eds.), The handbook of language socialization (pp. 391-420). Oxford: Wiley-Blackwell.

Gregory, E. (2001). Sisters and brothers as language and literacy teachers: Synergy between siblings. Journal of Early Childhood Literacy, 1(3), 301-322.

Gregory, E., Jessel, J., Islam, T., Kenner, C., \& Ruby, M. (2004). Children and their grandparents at home: A mutually supportive context for learning and linguistic development. The Canadian Journal of English in Education, 36(4), 16-24.

Gregory, E., \& Williams, A. (2000). Work or play? "Unofficial literacies" in the lives of two East London communities. In M. M. Jones \& K. Jones (Eds.), Multilingual literacies: Reading and writing different worlds (pp. 37-54). Amsterdam, Netherlands: John Benjamins.

Guerra, J. C. (1998). Close to home: Oral and literate practices in a transnational Mexicano community. New York: Teachers College Press.

Jamison, K. (2013). Making Kurdish public(s): Literacy practices and 
language politics in Turkey.

Presentation, Spencer Foundation Spring Retreat in Washington DC, March 21, 2013.

Jimenez, R., Smith, P., \& Teague, B. (2009).

Transnational and community literacies. Journal of Adolescent and Adult Literacy, 53(1), 16-26.

Johnson, G. (2013). “There is violence either way so let violence come with an education": Southern Sudanese refugee women's use of education for an imagined peaceful future. In L. Bartlett \& A. Ghaffar-Kucher (Eds.), Refugees, immigrants, and education in the global south: Lives in motion (pp. 70-84). New York: Routledge.

Johnson, K. (2013). Education for migrant children along the Thailand-Burma border: Governance and governmentality in a global policyscape context. In L. Bartlett \& A. Ghaffar-Kucher (Eds.), Refugees, immigrants, and education in the global South: Lives in motion (pp. 149-164). New York: Routledge.

Kalmar, T. M. (2000). Illegal alphabets and adult biliteracy: Latino migrants crossing the linguistic border. Mahwah, NJ: Lawrence Erlbaum Associates.

Karanja, L. (2010). An investigation into the educational experiences and support for urban Sudanese refugee children in Kenya: An ethnographic case study. Unpublished monograph, Villanova University.

Kenner, C., Ruby, M., Gregory, E., Jessel, J., \& Arju, T. (2007). Intergenerational learning between children and grandparents in East London. Journal of Early Childhood Research, 5(2), 219-243.

Kenner, C., Ruby, M., Jessel, J., Gregory, E., \& Arju, T. (2008). Intergenerational learning events around the computer: A site for linguistic and cultural exchange. Language and Education, 22(4), 298-319.

Kleifgen, J. (2001). Assembling talk: Social alignments in the workplace. Research on Language and Social Interaction, 34(3), 279-308.
Krashen, S. (1985). The input hypothesis: Issues and implications. London: Longman.

Lam, W. S., \& Rosario-Ramos, E. (2009). Multilingual literacies in transnational digitally mediated contexts: An exploratory study of immigrant teens in the United States. Language and Education 23(2), 171-90.

Lamphere Beryl, L. (2013). Language, literacy, and the practices of Pentecostals: An ethnography of the faith-based socialization of African migrants and their children in Massachusetts. Doctoral dissertation, Teachers College, Columbia University.

Lin, A. M. Y., \& Martin, P. (Eds.). (2005). Decolonisation, globalisation: Language-ineducation policy and practice. Clevedon, UK: Multilingual Matters.

Luykx, A. (2003). Weaving languages together: Family language policy and gender socialization in bilingual Aymara households. In R. Bayley \& S. Schecter (Eds.), Language socialization in bilingual and multilingual societies (pp. 25-43). Clevedon, UK: Multilingual Matters.

Makar, C. (2013). Celebrating language: The case of the New York State Spanish Spelling Bee. Unpublished Doctoral dissertation, Teachers College, Columbia University.

Martí, F., Ortega, P., Idiazabal, I. et al. (Eds.). (2005). Words and worlds: World languages review. Clevedon, UK: Multilingual Matters.

Mehfil-e-Mushaira. (2013). Urdu poetry competition. http:/ / www.mushaira.org/ competition.php (accessed November 24, 2014).

Menard-Warwick, J. (2007). Biliteracy and schooling in an extended-family Nicaraguan immigrant household: The sociohistorical construction of parental involvement. Anthropology and Education Quarterly, 38, 119-137.

Moon, S. (2011). Expectation and reality: Korean sojourner families in the UK. Language and Education, 25(2), 163-176. 
Nakamura, J., \& Quay, S. (2012). The impact of caregivers' interrogative styles in English and Japanese on early bilingual development. International Journal of Bilingual Education and Bilingualism, 15(4), 417-434.

Ochs, E., \& Schieffelin, B. (1983). Acquisition of conversational competence. London: Routledge, Kegan, \& Paul.

Onishi, N. (2008). "For English studies, Koreans say goodbye to Dad." New York Times, June 8.

Orellana, M., Reynolds, J., Dorner, L., \& Meza, M. (2003). In other words: Translating or "para-phrasing" as a family literacy practice in immigrant households. Reading Research Quarterly, 38(1), 12-34.

Orellana, M. F., Thorne, B., Chee, A., \& Lam, W. S. E. (2001). Transnational childhoods: The participation of children in the processes of family migration. Social Problems 48(4), 573-592.

Park, J. (2009) "English fever" in South Korea: Its history and symptoms. English Today 25(1), 50-57.

Pederson, J. (2011). Subtitling norms for television: An exploration focussing on extralinguistic cultural references. Amsterdam, Netherlands: John Benjamins.

Pennycook, A. D. (2000). English, politics, ideology: From colonial celebration to postcolonial performativity. In T. Ricento (Ed.), Ideology, politics and language policies (pp. 107-120). Amsterdam, Netherlands: John Benjamins.

Proctor, P., Sanee, S., \& Taffesse, W. (2009). Migrant schools: A human rights perspective: Inclusive education for Burmese migrants on the Thailand/ Burma border. 12th UNESCO-APEID International Conference: Bangkok, Thailand.
Rumbaut, R. (1994). The crucible within: Ethnic identity, self-esteem, and segmented assimilation among children of immigrants. International Migration Review, 28(4), 748-794.

Sailors, M., Hoffman, J., \& Condon, M. (2009). The challenges of developing leveled texts in and for developing countries. In E. Hiebert \& M. Sailors (Eds.) Finding the right texts, (pp. 70-85). New York: Guilford Press.

Sanchez, I. G., \& Orellana, M. F. (2006). The construction of moral and social identity in immigrant children's narratives-intranslation. Linguistics and Education, 17, 209-239.

Sax, D. (2013). A Punjabi broadcast draws in new hockey fans. New York Times. April 28.

Schieffelin, B., \& Ochs, E. (Eds.). (1986) Language socialization across cultures. Cambridge: Cambridge University Press. Shankar, S. (2004). Reel to real: Desi teens' linguistic engagements with Bollywood. Pragmatics, 14(2), 317-335.

Smith, P., \& Murillo, L. (2012). Research transfronterizo literacies in Texas border colonias. International Journal of Bilingual Education and Bilingualism, 15(6), 635-651.

Velasquez, K. (2013). Transcending linguistic boundaries at work: Latino and Korean immigrants in Koreatown, NYC. Anthropology News, 54(1). http:/ / www. scicornwall.com/2013/01/transcendinglinguistic-boundaries-at.html (accessed November 24, 2014).

Waltermire, M. (2012). The differential use of Spanish and Portuguese along the Uruguayan-Brazilian border. International Journal of Bilingual Education and Bilingualism, 15(5), 509-531.

Zentella, A. C. (1997). Growing up bilingual: Puerto Rican children in New York. Oxford: Blackwell Publishers. 